\title{
Educating Business Professionals For Year 2010 And Beyond: Six Critical Management Themes And Skills To Emphasize
}

Hamid Akbari, Northeastern Illinois University

\begin{abstract}
In this paper, based on the recent global and technological developments, I propose six critical themes/skills which need to be given a substantially more emphasis and coverage for educating business professionals in management for year 2010 and beyond. While there is interdependence among these six themes, they are separated for the reasons of focus and understanding.
\end{abstract}

Keywords: Management Education, Globalization, Diversity, Self Management, Information Overload, Online Management, Democracy and Human Rights

\section{INTRODUCTION}

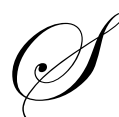

ince the turn of century, when Taylor (1911) and Weber (1947) gave rise to the idea of management of organizations as a profession, function and an academic discipline, management has become a mainstream field of education and practice. Grey (2005, p.53) notes that "Management has been one of the success stories of the modern world." Before Taylor, the term management coming from "the French menager and the Italian mnaeggiare - the first denoting domestic or household organization, the second the handling of horses" (Grey, p. 53), was not considered in high esteem in practical and educational terms (Grey, 2005). In the twentieth century, the rise of industrial societies in the world and the increasing rationalization of the organizations resulted in the emergence of management as a pre-eminent function as resonated by Drucker's 1955 assertion that "Management will remain a basic and dominant institution perhaps as long as Western Civilization itself will survive." (cf. Grey, 2005, p. 55). A look at the business sections of any newspaper and noting the number of books published on the subject of management and the celebrity status (e.g., Jack Welch) as well as notoriety (e.g., Jeff Skilling of Enron) of the CEOs, further attest to the prominence and significance of the field of management in today's world.

While in twentieth century the mainstream field of management education and practice has been dominated by a set of theories, writings and experiments set in motion by Taylor (1911), Weber (1947), Barnard (1936), Follett (1941), Roethlisberger and Dickson (1939), and many others, the imposing reality of a new global world dominated by Internet communication and easier and more prevalent transportation between the world continents and countries, has dramatically changed the landscape for management education and practice. Among three most important developments are the exponential rate of increase in the presence, use and impact of globalization, Internet and communication technologies on our everyday lives and experiences. These three, combined with the increasing pace and diversity of the populations immigrating to the western industrial societies, have already forced all fields, including management, to begin a process of developing new competencies for the present and future managers.

In this paper, I identify six management themes/skills which I propose to be given a heightened emphasis in educating and preparing managers for the year 2010 and beyond. They are: global thinking, diversity skills, online experience, universal demand for democracy and human rights, dealing with information overload, and managing 
oneself. The main reason for my proposal is that while there is a general understanding of the importance of at least some of these themes in the field, there is not sufficient research or educational materials involving their use in educating the business professionals. It is needless to state that this list is not exhaustive and it does not suggest that some other concepts such as leadership and ethics are less critical for the future generations of business professionals. The emphasis is rather on what is not yet at all or sufficiently covered in the field of management education.

\section{GLOBAL THINKING}

If we agree that globalization is a reality, then we should also agree that global thinking by managers and leaders is an imperative skill. The available evidence point to the fact that we are living in a global world (Clegg, Kornberger and Pistsis, 2005). While it is true that international trade and interaction has been in existence throughout the history in human societies, the phenomenon of globalization is quite recent. Therborn (2000, p. 159, cf., Clegg, et. al., 2005, p. 453) notes:

in the major dictionaries of English, French, Spanish and German of the 1980s the word [globalization] is not listed. In Arabic at least four words render the notion. Whereas in Japanese business the word goes back to the 1980s, it entered academic Chinese only in the mid-1990s. The Social Science Citation Index records only a few occurrences of 'globalization' in the 1980s but shows its soaring popularity form 1992 onwards, which accelerated in the last years of the past century.

This shows - unlike what may seem to be by now a old theme - that the realization of globalization is a very recent phenomenon. However, the reality has already exceeded the present management's literature and educational materials for responding to its demands. This means that business educators must increasingly include global writings, thinking, cases and examples in their coverage of the materials. As educators, it is not sufficient anymore to talk about the reality of globalization; we must raise the bar by actually demonstrating to our students how we, ourselves, think and teach globally. For example, no Strategic Management theory and approach should be presented without dealing with its global aspects. More specifically, Porter's generic strategy of cost leadership must include a consideration of how a cheaper product produced elsewhere in the world can at anytime enter into competition with the particular company which is developing a low cost strategy. For another example, global thinking will require us to think of how every change in academic standards of student admissions and tuition structure at our universities, will not only impact our traditional students but also our international students.

The main argument here is that much more emphasis and teaching resources and techniques need to be devoted to globalization than before. Differently said, to those who may argue that globalization is already given enough emphasis, I reply that so far we have only seen the tip of the iceberg.

\section{DIVERSITY SKILLS}

There is only one trend in the diversity of the populations throughout the world and especially in the United States, Europe and industrial world: more diversity. Teaching and learning about how to effectively lead and manage diverse workforces is going to become increasingly more critical. Relating to many people from many parts of the world with different worldviews is going to be ten times more important in the next five years, than it has been in the last five years. The immigration trend in the United States portends of a population by around year 2050 that is not anymore composed of a white Angelo Saxon majority. Hispanic population rise is so rapid that it has prompted a major political writer, Samuel Huntington (2004) to pose his controversial identity question of "who are we?" This question has been and needs to be further debated and challenged in critical and constructive terms. The reality, however, is that the world, and not just the United States, is moving towards more population diversity. Most fortunately, the United States, being historically an immigrants' country and a country welcoming immigrants better than any other place on earth, is very well equipped to treat diversity in positive rather than negative terms. Based on this simple and undeniably existing trend toward more diversity, this author strongly suggests that diversity must be embraced and should be promoted as an opportunity for harmony, peace and progress of the mankind inside and outside the United States. 
As for practical and business applications, the future managers must learn more about what is diversity, how to be comfortable with it, how to relate to different cultures, and how to lead and motivate employees via understanding their cultural diversity. For a specific example, sometimes ago, the author teaching an MBA course was asked by a student and manager in his class about how to bring about a change agenda within a primarily diverse and immigrant workforce in his Schaumberg based company. From the conversation, I found out that most of the employees were of Hispanic origin. Since this was during the world cup soccer in June/July 2006, my first question for the student was whether he knows anything about soccer. He replied not really. I advised him to understand soccer better for being able to share the passion for soccer with his Hispanic employees, before being able to embark on any change conversation about their work.

This simple example, by no means, reveals the complexity of diversity or the intended change in that situation. However, it points out to the fact that diversity competency in management, requires much more than the traditional notions of management. Beyond and beneath the soccer there is of course, a necessary understanding of the diverse workforce's cultural, historical, social and political backgrounds and affinities of the organizational members. Moreover, this understanding of diversity is not just for the so called non-diverse white Anglo-Saxon population, it is for all populations. Accordingly, the immigrants to the US also need to learn and understand about baseball and American football (e.g., Gannon, 2003). Most importantly, an effective display of diversity skills requires a clear commitment to listening and learning from the diverse workforce about their views, concerns and ideas.

\section{ONLINE MANAGERIAL SKILLS}

Every manager we train and educate has two lives, offline and online. Our management literature, writings and knowledge remain replete and delimited by our existence in an offline world and its related set of theories and skill sets. There is practically none that deals with online theoretical and practical models in online and virtual managing. While most of us and our students and practicing managers know about the significance of Internet, Email, Websites and B-logs, we know essentially none about how to effectively manage our organizations online or electronically. In contrast, there is a lot that is known about E-commerce in marketing literature.

To illustrate the point, an electronic search by this author under the topics of E-management on EBSCOhost database at my university's library website resulted in essentially no journal articles on E-management and rather produced articles with such titles: "Getting the most out of reverse $\boldsymbol{e}$-auction investment," and "Application of a quantitative risk assessment method to emergency response planning." As for the author's search under the keyword of E-leadership, the emerging titles at the first glance created more hopes which were soon dashed by the a more careful review of the articles' content. For example, an article titled: "Leading from day one," by John West (2006, p. 52), dealt with "developing leadership skills that would be advantageous to building a career in the field of information technology."

Against this reality, we must begin researching, learning and training our students in effective online skills for managing and leading people. By this, I do not mean giving lessons to students in how to compose an E-mail, etc. Rather, I am suggesting development of a set of theories and approaches in providing a better grasp of the online and virtual reality of organizations to our students. The traditional topics in management, such as organization theory and design, motivation, team building, decision making and leadership need to address the reality of online life. For one significant example, there is no mention of the online tasks of managers in Mintzberg's (1973) classical work on managerial functions. Unlike the time of Mintzberg's study, today organizational members and employees live a significant amount of their work hours online and so it is needed that managers, leaders and educators heed this reality. Of all the themes proposed in this article, we know the least about this one and we need to do the most to enhance it.

\section{UNIVERSAL DEMAND FOR DEMOCRACY AND HUMAN RIGHTS}

Underlying the above themes are two ideas that pervade and permeate them: the spirit and era of democracy and the concept of universality of human rights. Whereas since the Russian Revolution of 1917 until the 
collapse of communism in 1990s there were two competing political themes segregating the world system and people, communism vs. democratic capitalism, there is now only two that unify most of the world's population: democracy and human rights. No manager in this decade and beyond will survive if she does not understand the basic concepts, practices and the required respect for these two universally popular and on demand concepts.

The basic idea behind human rights is that there are a set of fundamental rights that everyone everywhere in the world is entitled to. These rights among many others include: freedom of speech, association and expression. The basic idea behind democracy, since the ancient times - albeit on an evolutionary path - has been the right of each person to participate in the government and administration of the affairs of the organization which governs her. More and more people everywhere in the world and especially in the industrial societies and even in essentially the last large communist country, China, seem to have a basic grasp of the notions included and advanced by these ideas. And for this simple reason combined with the compelling evidence available, the managers need to understand both of these concepts and apply them in their practice in organizations.

Pragmatically, managers more than ever need to have the participation of all organizational members in setting the agenda and processes for achieving organizational goals. This may mean the sheer abolition of certain organizational systems such as mechanistic structures and the adoption of organic structure as the primary model of organizing (e.g., Burns and Stalker, 1961), and then modifying it subject to enhancing and or preserving its democratic features and mechanisms. As for human rights, the rights of every individual to free expression (e.g., whistle blowing), and association (e.g., local unions or possible organizing into new global unions) should be recognized and actively respected. At the very least, the main idea here is that the managers need to be well versed in the concept and application of these two universally present and popular ideas that everyday more people seem to embrace and subscribe to. The management of today and especially tomorrow cannot be effective without including them in their routine practice.

\section{DEALING WITH INFORMATION OVERLOAD}

Globalization, diversity, online life, and democratic and right filled participation, all mean the exponential increase in the amount of information available and accessible, which un-doubtly translates into a huge and permanent information overload for almost any decision we make. This phenomenon has long been noted by the Nobel Laureate and organizational writer, Herbert Simon. In his famous theory of bounded rationality, Simon (1976) states that in decision making, organizational actors satisfice rather than maximize the outcomes of their decision by selectively choosing and attending to the information. This is in contrast to the rational requirement of analyzing all available data and all possible outcomes of their decision alternatives before making a final decision. Meanwhile, the dimensions of the information accessibility and overload in light of the online, global and diversity currents are now much more acute than Simon first noted this problem. Partially this problem in certain respects can be dealt with increasingly advanced versions of computers. However, the ultimate non-routine decisions both today and in future are made by the human beings who are already overwhelmed by the enormity of the information overload (e.g., Sunstein, 2006).

This overload, while impacting every area of life within organizations, is especially critical in the area of sensing and interpreting environments of business organizations (Huber, 2004). Huber notes that business press and literature have already lagged in preparing managers for dealing with the future (vs. the past) business environments. He suggests that five forces have and will continue to substantially change the environmental landscape of organizations. They are (p. 15):

1. more and increasing scientific knowledge,

2. increasingly effective information, transportation, and manufacturing Technologies,

3. more and increasing complexity,

4. more and increasing dynamism, and

5. more and increasing inter-firm competitiveness." 
Thus the existing and increasing reality is the presence of information overload and rapid pace of change in producing them, which bring up the question of how to deal with it. Huber and others advocate many solutions to this reality. One that this author strongly recommends is the diversification of the sources of information to the extent feasible. Contradictory sources of information must be searched and opposing views must be more frequently sought in order to increase the probability of sensing and interpreting the environments correctly. Moreover, business professionals must be taught to identify and question their assumptions, values and beliefs which underlie their decisions.

A way to manage information overload is to redesign organizations. For this, Huber (p. 65) recommends "it will be more important for future firms, facing, as they will, more frequent and more rapidly occurring environmental changes, to ensure that upward communication channels are easily traversed." An example he provides from Intel's Andy Grove is illuminating (p.65):

[A strategic inflection point] can be a major change due to the introduction of new technologies, a different regulatory environment, a change in customers' values, or a change in what customers prefer. Almost always it hits the corporation in such a way that those of us in senior management are among the last ones to notice. (Puffer, 1999: 15-16)

\section{MANAGING ONESELF}

The developments and realities addressed so far, globalization, diversity and online life, human rights, democracy, and information overload, have all but made and will further make the practice of management more complex and difficult. While Taylorism attempted to make it easier to manage workers whose jobs was only to do what the management controls, the notions of diversity, globalization and human rights among others will make it essentially impossible to follow Taylorism. Workers and employees everywhere claim to have certain universal rights and present a unique identity that cannot be anymore captured in the mere division between workers and managers. We are all human beings, unique in terms of our diversity and universal in terms of our inalienable human rights, and we demand a democratic voice in our organizations. If this reality seems not be here yet in entirely, it is on its way. And this means, managing others will become harder to the extent that we do not manage ourselves effectively. Managing ourselves means that we need to know our own personalities, weaknesses and strengths and thereby learning not only our uniqueness and independence from others, but more importantly our dependence on other people for their thinking heads and helping hands.

There is already a movement toward this in the field of management. Harvard Business Review, as the most widely read business and management publication in the world, includes a regular feature on managing oneself. Warren Bennis (1989 and with Nanus, 2003) has been advocating the knowledge of self as an important pre-requisite for effective leadership. Yet, in none of the mainstream organizational behavior or management textbooks we find an extensive, or in fact any coverage of this very important topic. We need to do much better here as time and time again, we have seen how the leaders and managers, who did not manage themselves effectively, including their successes, have failed as managers and leaders. Kennth Lay of Enron failed as he did not manage his insatiable greed. A few managers that I knew, despite their otherwise good managerial skills, failed as they did not manage their own destructive dependencies, such as alcoholism or anger. Of course, as these are more tabloid examples, there are also more mundane ones, such as a manager, not understanding his own biases, makes a bad promotional decision and therefore turns his otherwise talented employee to leave the organization. There is a large territory that needs to be known, covered and discovered in the management of self, a most critical and neglected area in management education.

\section{SUMMARY AND CONCLUSION}

The global, technological and communication revolutions in the world today require a commensurate adjustment in the critical educational themes and skills to be provided to the future generation of business professionals. Weick (2007) suggests an evaluation of the tools, practical or conceptual, that we hold on for too long, which, prevent learning and adopting the new ones. We can no more work with the theories and models which 
were set in motion by the writers and practitioners in early twentieth century, such as Taylor, Weber and Mayo. There are at least six critical themes and skills that need to be brought to the forefront of our educational work for the future managers. They are: global thinking, diversity competency, online management, recognition of universal demand for democracy and human rights, dealing with information overload, and managing oneself. This author has no doubt that any educational agenda void of all or most of these themes will be ineffective in educating and training business professionals in year 2010 and beyond.

\section{REFERENCES}

1. Barnard, C. (1936). The functions of executive. Cambridge: Harvard University Press.

2. Bennis, W. G. (1989). On becoming a leader. New York: Perseus Books.

3. Bennis, W. G. \& Nanus, B. (2003), Burt. leaders: Strategies for taking charge. New York: Harper.

4. Burnes, T. \& Stalker, G. M. (1961). The management of innovation. London: Tavistock.

5. Clegg, S., Kornberger, M. \& Pitsis, T. (2005). Managing and organizations: An introduction to theory and practice. London: Sage Publications Ltd.

6. Follett, M. P. (1941). Dynamic administration: The collected papers of Mary Parker Follett, edited by H. C. Metcalf and L. Urwick. New York: Harper \& Brothers.

7. Gannon, M. (2003). Understanding global cultures: Metaphorical journeys through 28 Nations, clusters of nations and continents. Thousands Oaks, California: Sage Publications.

8. Grey, C. (2005). A very short, fairly interesting and reasonably cheap book about studying organizations. Thousand Oaks: Sage Publications Ltd.

9. Huber, G. P. (2004). The necessary nature of future firms: Attributes of survivors in a changing world. Thousand Oaks: Sage Publications Ltd.

10. Huntington, S. P. (2004). Who are we: The challenges to America's national identity. New York: Simon and Schuster.

11. Mintzberg, H. (1973). The nature of managerial work. New York: Harper \& Row.

12. Roethlisberger, F. J., \& Dickson, W. J. (1939). Management and the worker. Cambridge:Harvard University Press.

13. Simon, H. A. (1976). Administrative behavior: A study of decision making processes in administrative organization. New York: Free Press.

14. Sunstein, C. R. (2006). Infotobia: How many minds produce knowledge. New York: Oxford University Press.

15. Taylor, F. W., 1967. Principles of scientific management. New York: Harper (First Published in 1911).

16. Weber, M (1947). The theory of social and economic organization, translated by T. Parsons and A. M. Henderson. New York: Free Press.

17. Weick, K. D. (2007). Drop your tools: On reconfiguring management education. Journal of Management Education. 31(1), 5-16.

18. West, J. E. (2006). Leading FROM day one. Computerworld, 40 (41), 52-52. 